\title{
$\mathrm{Nb}$ 활용 탄질소 스테인리스강의 부동태 및 대기산화 피막 보호성 연구
}

\author{
이창근 ${ }^{1,2} \cdot$ 하헌영 $^{2 *} \cdot$ 이태호 $^{2} \cdot$ 조경목 $^{1, *}$ \\ ${ }^{1}$ 부산대학교 재료공학과 \\ ${ }^{2}$ 재료연구소 철강재료연구실
}

\section{Evaluation of the Protective Ability of Air-formed Oxide and Passive Films Formed on Nb-Bearing High Interstitial Stainless Steels}

\author{
Chang-Geun Lee ${ }^{1,2}$, Heon-Young $\mathrm{Ha}^{2 *}$, Tae-Ho Lee ${ }^{2}$, and Kyung-Mox Cho ${ }^{1, *}$ \\ ${ }^{1}$ Department of Materials Science and Engineering, Pusan National University, Busan 46241, Republic of Korea \\ ${ }^{2}$ Ferrous Alloy Department, Korea Institute of Materials Science, Changwon 51508, Republic of Korea
}

\begin{abstract}
The effects of $\mathrm{Nb}$ on grain refinement and the pitting corrosion resistance of $\mathrm{Fe}_{\text {balance }} 18 \mathrm{Cr} 10$ $\mathrm{Mn} 0.3 \mathrm{C} 0.3 \mathrm{NxNb}(\mathrm{x}=0.1$ and $0.2 \mathrm{wt} \%$ ) high interstitial alloys were investigated through microstructure analysis and potentiodynamic polarization tests. The resistance to pitting corrosion of the two alloys, covered with a passive film and an air-formed oxide films, was also examined. As the $\mathrm{Nb}$ content increased from 0.1 to $0.2 \mathrm{wt} \%$, the grain size decreased, the volume fraction of $\mathrm{Nb}(\mathrm{C}, \mathrm{N})$ particles increased, and the pitting potential was elevated. In addition, the two alloys covered with the passive film exhibited higher pitting potentials than the alloys with the air-formed oxide films. The physico-chemical and electronic properties of the passive film formed in an aqueous environment, and air-formed oxide of the two alloys were examined using X-ray photoelectron spectroscopy and Mott-Schottky analysis. As a result, it was revealed that the defect density level in the passive film was the dominant factor in determining the pitting corrosion resistance of the specimens. $\mathrm{Nb}$ addition was found to promote the formation of a protective passive film with low defect density, which resulted in the increase in the pitting potential. Moreover, the fact that the point defect density of the passive film was smaller than the air-formed oxide films was observed in both alloys, which can explain the higher pitting corrosion resistance of the passivated specimen than the specimen covered with an air-formed oxide film.
\end{abstract}

(Received July 5, 2017; Accepted September 25, 2017)

Keywords: high interstitial alloys, Nb, grain refinement, pitting corrosion, Mott-Schottky analysis

\section{1. 서 론}

$\mathrm{FeCrNi}$ 기지 상용 300계열 오스테나이트 스테인리스강은 기계적 특성과 내식성의 조합이 우수하여 다양한 스테인리 스강 사용처에 널리 적용되고 있다. 그러나 기존 $\mathrm{FeCrNi}$ 계 스테인리스강은 $\mathrm{Ni}$ 의존도가 높아 비경제적이면서 가격변동 성이 큰 단점이 있어, 이를 극복하기 위한 대체재의 연구개발 이 활발히 진행되었다. 상용 $\mathrm{FeCrNi}$ 계 합금의 대체소재 중 하나로, $\mathrm{Mn}, \mathrm{N}$ 및 $\mathrm{C}$ 를 이용하여 오스테나이트상을 안정화한 탄질소 복합 첨가강(high interstitial alloy, HIA)이 제안되었

* Corresponding Author: Heon-Young Ha, Kyung-Mox Cho [Tel: +82-55-280-3422, +82-51-510-3218

E-mail: hyha2007@kims.re.kr, chokm@pusan.ac.kr]

Copyright (c) The Korean Institute of Metals and Materials
다 [1-5]. 침입형 원소인 $\mathrm{N}$ 과 $\mathrm{C}$ 는 스테인리스강의 강도를 증 가시키면서도 연성은 크게 감소시키지 않는 효과가 있으며 [1-4], 고용상태의 $\mathrm{N}$ 과 $\mathrm{C}$ 는 스테인리스강의 공식저항성 또한 향상시키는 것으로 보고되었다 [6-10]. 그러나 HIA는 침입형 원소의 함량이 높으므로 $([\mathrm{N}+\mathrm{C}] \geq 0.4 \mathrm{wt} \%)$, 강의 제조 후 후속 열처리 과정 중 $\mathrm{Cr}_{23} \mathrm{C}_{6}$ 또는 $\mathrm{Cr}_{2} \mathrm{~N}$ 등의 탄질화물이 형성 되기 쉽다. 이를 방지하기 위해서는 균질화 열처리 온도 상승 이 할 필요한데 [10-13], 이는 결정립의 성장을 초래하여 기 계적 물성의 저하를 가져올 위험이 있다. 따라서 본 연구팀은 결정립 성장과 탄질화물 형성을 억제하기 위하여 $\mathrm{Nb}$ 를 소량 활용하는 방법을 도입하였다.

$\mathrm{Nb}$ 는 강력한 탄질화물(MX-type) 형성원소이기에 기존 $\mathrm{HIA}$ 설계·개발에서 적극적으로 고려되지 않았으나, 본 연구 
Table 1. Chemical compositions of the $0.1 \mathrm{Nb}$ and $0.2 \mathrm{Nb}$ alloys (in wt $\%$ ).

\begin{tabular}{ccccccc}
\hline Alloy & $\mathrm{Fe}$ & $\mathrm{Cr}$ & $\mathrm{Mn}$ & $\mathrm{N}$ & $\mathrm{C}$ & $\mathrm{Nb}$ \\
\hline $0.1 \mathrm{Nb}$ & Balance & 18.29 & 10.38 & 0.29 & 0.30 & 0.10 \\
$0.2 \mathrm{Nb}$ & Balance & 18.21 & 10.49 & 0.29 & 0.30 & 0.20 \\
\hline \multicolumn{7}{c}{$\mathrm{Ni} \leq 0.008, \mathrm{Si} \leq 0.20, \mathrm{~S} \leq 0.005, \mathrm{P} \leq 0.004$} \\
\hline
\end{tabular}

팀의 선행연구 결과, $\mathrm{Fe}_{\text {balance }} 18 \mathrm{Cr} 10 \mathrm{Mn} 0.3 \mathrm{~N} 0.3 \mathrm{C}$ 기지의 오 스테나이트계 스테인리스강에 $\mathrm{Nb}$ 를 0-0.5 wt\%까지 첨가한 합금의 미세조직, 기계적 특성 및 공식저항성을 조사하였고 $\mathrm{Nb}(\mathrm{C}, \mathrm{N})$ 이 고온에서 결정립의 이동을 억제하여 결정립 성장 이 효과적으로 제어됨으로써 기계적 특성이 향상되었으며, 나아가 조대한 $\mathrm{Nb}(\mathrm{C}, \mathrm{N})$ 이 형성됨에도 불구하고 $0.2 \mathrm{wt} \%$ 까 지의 $\mathrm{Nb}$ 의 첨가는 공식저항성을 향상시킴을 확인하였다 $[14,15]$. 특히, $\mathrm{Nb}$ 첨가로 인해 내공식성이 향상된 $\mathrm{Fe}_{\text {balance }}$ $18 \mathrm{Cr} 10 \mathrm{Mn} 0.3 \mathrm{~N} 0.3 \mathrm{C}(0.1,0.2) \mathrm{Nb}$ 합금은 상용 304 또는 $316 \mathrm{~L}$ 스테인리스강보다도 우수한 공식저항성을 가지는 것으로 확 인되었다 [14].

공식저항성은 스테인리스강 표면에 형성된 부동태 피막의 보호성에 민감하게 의존하고, 피막의 보호성은 피막의 물리화학적 및 전자적 특성에 따라 변화하기 때문에 $[16,17]$, 소량 의 $\mathrm{Nb}$ 첨가에 따른 HIA의 공식저항성의 향상을 이해하기 위 해서는 부동태 피막의 물리-화학적 및 전자적 특성 연구가 필 요하다. 또한, 본 연구의 대상 소재인 $\mathrm{Fe}_{\text {balance }} 18 \mathrm{Cr} 10 \mathrm{Mn} 0.3$ $\mathrm{N} 0.3 \mathrm{C}$ 기지 합금은 상용 300 계 오스테나이트 스테인리스강 의 대체재로서 개발한 소재이므로, 기존 300 계 스테인리스강 이 주로 사용되는 부식환경을 고려할 때 대기 중 형성되는 산 화피막 및 수용액 중 형성되는 부동태 피막의 특성이 모두 연 구될 필요가 있다. 따라서 본 연구에서는 $\mathrm{Fe}_{\text {balance }} 18 \mathrm{Cr} 10$ $\mathrm{Mn} 0.3 \mathrm{~N} 0.3 \mathrm{C}(0.1-0.5) \mathrm{Nb}$ 합금 중 가장 우수한 내공식성을 나 타낸 $\mathrm{Fe}_{\text {balance }} 18 \mathrm{Cr} 10 \mathrm{Mn} 0.3 \mathrm{~N} 0.3 \mathrm{C}(0.1,0.2) \mathrm{Nb}$ 의 2종 합금에 대하여, 공식저항성 평가 및 두 합금의 부동태 피막과 대기산 화 피막의 물리적, 전자적 특성을 분석하였고, 이를 바탕으로 공식저항성의 변화를 해석하였다.

\section{2. 실험방법}

시험에 사용된 합금은 $\mathrm{Fe}_{\text {balance }} 18 \mathrm{Cr} 10 \mathrm{Mn} 0.3 \mathrm{~N} 0.3 \mathrm{C}$ 기지에 $\mathrm{Nb}$ 를 각각 $0.1,0.2 \mathrm{wt} \%$ 포함한 HIA 2종이다. 합금의 상세 조성 및 표기방법은 표 1 에 나타내었다. 합금 제조를 위하여 가압유도용해로(VTC $200 \mathrm{~V}$, Indutherm, Germany)를 사용하 여 주괴를 제조하였고 열간압연(압연종료온도 $\left.1050{ }^{\circ} \mathrm{C}\right)$ 하여
$4 \mathrm{~mm}$ 두께의 판재로 성형하였다. 열간압연 판재는 $1100{ }^{\circ} \mathrm{C}$ 에서 1 시간 동안 유지하여 균질화한 후 수냉하였다. 균질화 열처리 온도는 평형상태도 계산(ThermoCalc. Software, version 3.0, TCFE 7.0 database)을 통해 결정하였다.

미세조직 관찰을 위해 시편을 다이아몬드 현탁액을 사용 하여 $1 \mu \mathrm{m}$ 까지 연마한 후 화학적 에칭 $\left(20 \mathrm{ml} \mathrm{HNO}_{3}+30 \mathrm{ml}\right.$ $\mathrm{HCl}+50 \mathrm{ml}$ ethanol 혼합용액)을 하였고 주사전자현미경 (scanning electron microscope, SEM, JSM-7100F, JEOL, Japan)을 이용하여 조직을 관찰하였다. SEM 사진을 이용하 여 $\mathrm{Nb}(\mathrm{C}, \mathrm{N})$ 의 부피분율을 측정하였고, 미국시험재료협회 (American society for testing materials, ASTM) E-112의 방 법에 따라 결정립 크기를 조사하였다.

본 연구에서는 대기산화 피막 및 부동태 피막 형성조건 각 각에서 두 합금의 공식저항성을 평가하였다. 부동태 피막은 연마 후 즉시 수용액에 침지하여 정전위법으로 형성하였고, 대기산화 피막은 각 샘플의 표면을 연마한 후 상온의 대기에 서 1 시간 동안 방치하여 형성하였다. 전기화학시험을 위하여 각 샘플을 $\mathrm{SiC}$ 연마지를 이용하여 \#1500까지 연마하였고, 도 금 테이프를 이용하여 반응 면적을 $0.13 \mathrm{~cm}^{2}$ 가 되도록 제어 하였다. 모든 전기화학 실험은 3-전극 전기화학 시스템 $(\mathrm{Pt}$ 상 대전극, 포화 감홍 기준전극, 시편(작동전극))에서 수행되었 고 시험온도를 $25{ }^{\circ} \mathrm{C}$ 로 제어하였다. 각 시험은 반복측정을 통해 재현성을 확인하였다.

두 합금의 부동태 피막과 대기산화 피막의 공식저항성을 평가하기 위하여 염화이온을 포함 $(0.6 \mathrm{M} \mathrm{NaCl})$ 하는 boratephosphate-citric 완충용액 $\left(0.2 \mathrm{M} \mathrm{H}_{3} \mathrm{BO}_{3}+0.05 \mathrm{M} \mathrm{C}_{6} \mathrm{H}_{8} \mathrm{O}_{7}\right.$. $\mathrm{H}_{2} \mathrm{O}+0.1 \mathrm{M} \mathrm{Na}_{3} \mathrm{PO}_{4} \cdot 12 \mathrm{H}_{2} \mathrm{O}, \mathrm{pH}$ 8.5)에서 양극분극시험을 전 위 주사 속도 $2 \mathrm{mV} / \mathrm{s}$ 및 $5 \mathrm{mV} / \mathrm{s}$ 로 수행하였고 이 결과로부터 공식전위(pitting potential, $\mathrm{E}_{\mathrm{pit}}$ )을 측정하였다. 공식발생처 관 찰을 위해, 두 샘플을 $0.1 \mathrm{M} \mathrm{NaCl}+1 \mathrm{M} \mathrm{HCl}$ 용액에서 10 분간 침지한 후 부식 발생 표면을 SEM으로 관찰하였다. 이후, 공식 저항성 변화 해석을 위하여, 두 합금의 부동태 피막과 대기산 화 피막의 특성을 규명하기 위한 실험을 진행하였다. 피막 분 석을 위해서는 $\mathrm{Cl}^{-}$을 포함하지 않는 borate-phosphate-citric 완 충용액 $(\mathrm{pH}$ 8.5)을 이용하였다. 피막분석에 앞서, 양극분극시 험을 통해 두 합금의 분극거동 및 부동태 피막 형성 전위 영역 을 파악하였다. 이후, 두 합금을 각각 (1) 대기 중 3시간 유지하 여 대기산화피막을 형성하고, (2) 완충용액 중 부식전위 (corrosion potential, $\mathrm{E}_{\mathrm{corr}}$ )에서 3시간 유지하여 부동태 피막을 형성한 후 두 유형의 피막 별 두께에 따른 화학적 조성 변화를 $\mathrm{X}$ 선 광전자 분석법(X-ray photoelectron spectroscopy, XPS, 
(a)

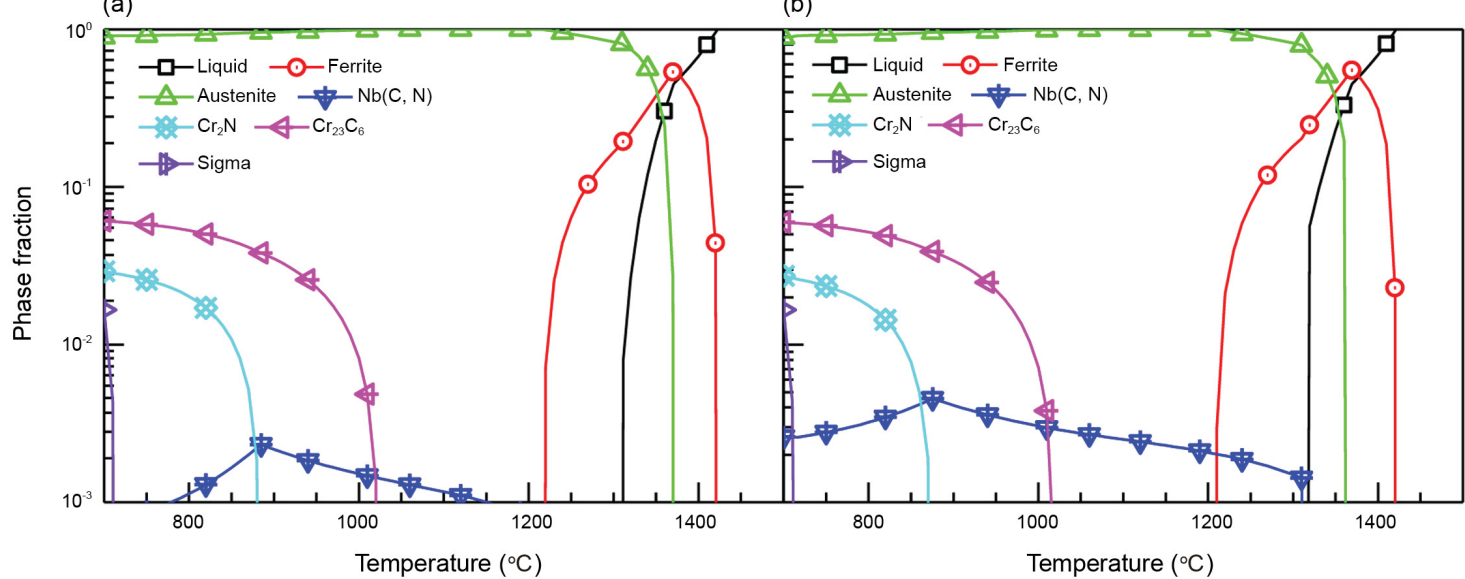

Fig. 1. Equilibrium phase diagrams of (a) $0.1 \mathrm{Nb}$ and (b) $0.2 \mathrm{Nb}$ alloys calculated using a Thermo-Calc. software.

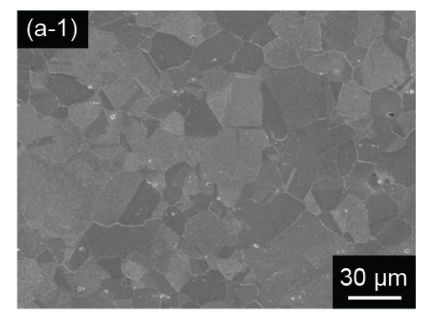

\section{(b-1)}
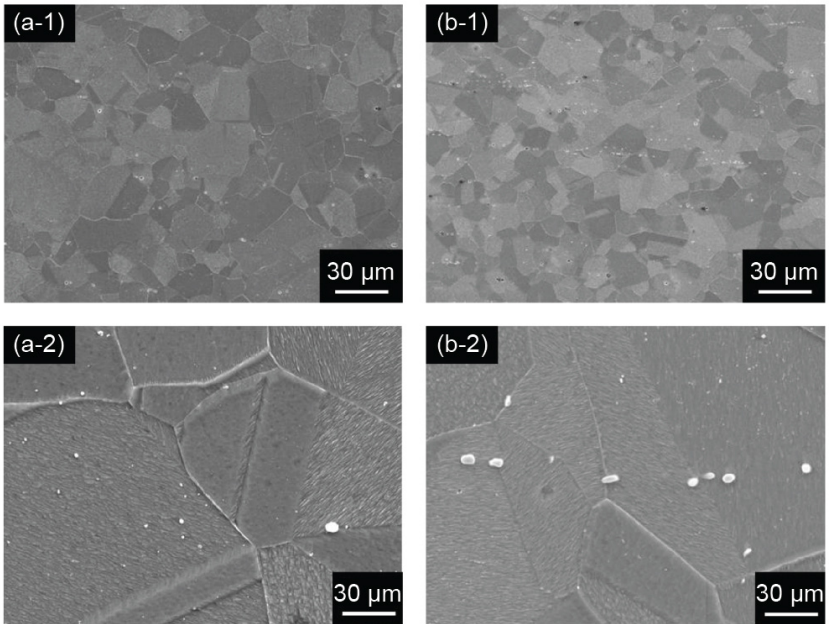

\section{(b-2)}

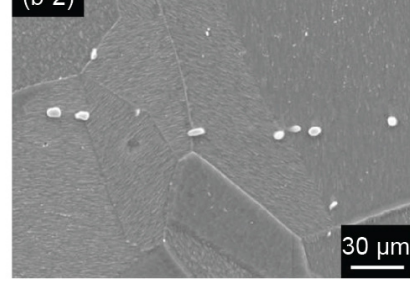

Fig. 2. SEM micrographs of (a) $0.1 \mathrm{Nb}$ and (b) $0.2 \mathrm{Nb}$ alloys taken at (a-1 and b-1) low and (a-2 and b-2) high magnifications.

PHI 5000 VersaProbe, ULVAC-PHI, Japan)를 이용하여 측정 하였다. XPS 분석은 Al-K $\alpha$ anode X-ray 소스(source) (150 W, $\mathrm{h} \nu=15 \mathrm{kV})$ 을 이용하여 분석하였다. 두 합금의 부동태 피막과 대기산화 피막 내 점결함농도 측정을 위하여 Mott-Schottky 분석 수행하였다. 이를 위하여, 완충용액에서 $0.5 \mathrm{~V}_{\mathrm{SCE}}$ 에서 30 분 동안 유지하여 부동태 피막을 형성하였고, 대기 중 1 시간 동안 방치하여 대기산화 피막을 형성하였다. 준비된 시편에 대해, 인가전위 $0.5 \mathrm{~V}_{\mathrm{SCE}}$ 로부터 음(-)방향으로 전위를 주사(전 위주사 속도 $=-10 \mathrm{mV} / \mathrm{step}, 1 \mathrm{kHz}$, 전위진폭 $= \pm 10 \mathrm{mV}$ )하여 피막의 정전용량을 측정하고 이로부터 점결함농도를 측정하 였다.
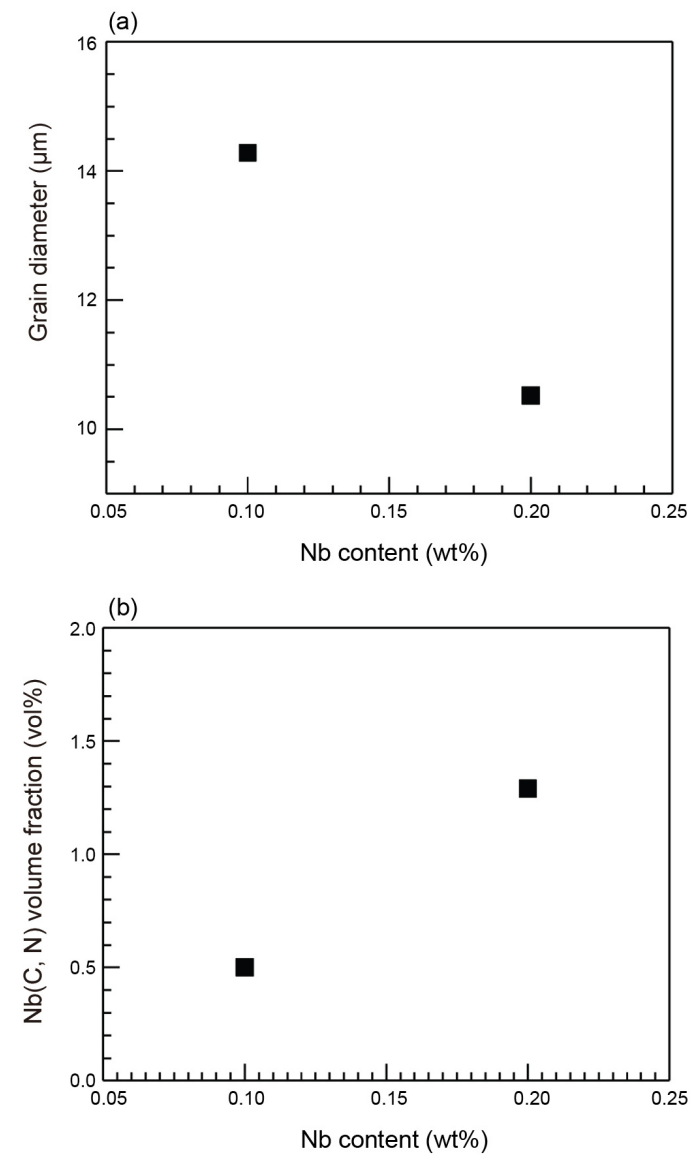

Fig. 3. Variations of (a) grain diameter and (b) $\mathrm{Nb}(\mathrm{C}, \mathrm{N})$ volume fraction as a function of the $\mathrm{Nb}$ content. 
(a)

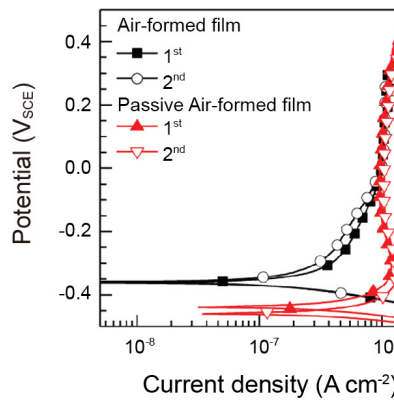

(b)

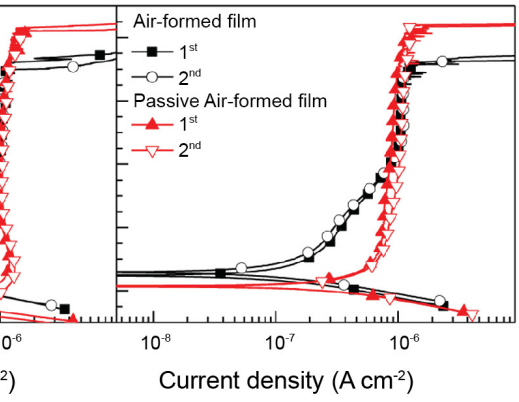

(c)

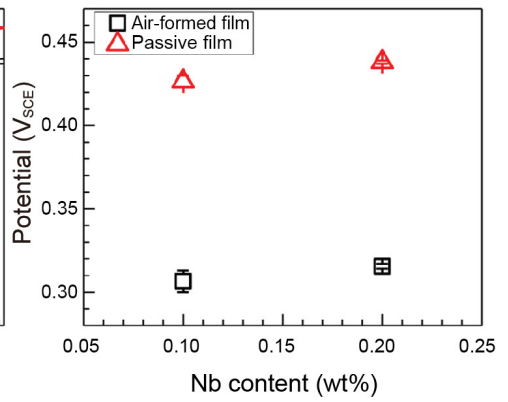

Fig. 4. Potentiodynamic polarization curves of (a) $0.1 \mathrm{Nb}$ and (b) $0.2 \mathrm{Nb}$ alloys measured in a buffered $0.6 \mathrm{M} \mathrm{NaCl}$ solution (borate-phosphate-citric buffer, $\mathrm{pH} 8.5$ ) at $25{ }^{\circ} \mathrm{C}$ at a potential sweep rate of $2 \mathrm{mV} / \mathrm{s}$. (c) Pitting potential values of the specimens.

\section{3. 결과 및 고찰}

\section{1. 미세조직}

그림 1 은 $0.1 \mathrm{Nb}$ 및 $0.2 \mathrm{Nb}$ 합금의 평형상태도를 보여준다. 상태도로부터, 두 합금을 $1100{ }^{\circ} \mathrm{C}$ 에서 균질화 열처리 하였을 때 $\mathrm{Nb}(\mathrm{C}, \mathrm{N})$ 을 제외한 $\mathrm{Cr}_{23} \mathrm{C}_{6}, \mathrm{Cr}_{2} \mathrm{~N}$, sigma 등의 다른 석출상 이 없는 오스테나이트 상이 형성되고 $\mathrm{Nb}$ 의 함량이 증가할수 록 $\mathrm{Nb}(\mathrm{C}, \mathrm{N})$ 의 상분율 또한 증가할 것을 예측할 수 있다.

그림 2는 두 합금의 균질화 열처리 후 SEM 조직 사진을 보 여준다. 그림 2(a-1), 2(b-1)는 두 합금이 소량의 $\mathrm{Nb}(\mathrm{C}, \mathrm{N})$ 와 오스테나이트 기지로 구성된 미세조직을 보여주며 이는 상 태도(그림 1)에서 예측된 바와 잘 일치한다. 또한 두 합금 모 두에서 $\mathrm{MnO}$ 및 $\mathrm{MnS}$ 등의 비금속 개재물은 관찰되지 않았 고, 모재 내 $\mathrm{Nb}(\mathrm{C}, \mathrm{N})$ 이 분포되어 있는 상태와 결정립계에 다 른 제 2상 석출이 발생하지 않았음을 그림 2(a-2), 2(b-2)로부 터 확인할 수 있다. 그림 2로부터, 관찰된 $\mathrm{Nb}(\mathrm{C}, \mathrm{N})$ 은 조대한 $\mathrm{Nb}(\mathrm{C}, \mathrm{N})($ 크기 0.5-5 $\mu \mathrm{m})$ 및 미세한 $\mathrm{Nb}(\mathrm{C}, \mathrm{N})($ 크기 $10 \mathrm{~nm}$ 이 하)의 두 종류가 존재하며 $\mathrm{Nb}$ 함량이 증가하면 $\mathrm{Nb}(\mathrm{C}, \mathrm{N})$ 부 피분율이 증가하는 것이 확인되었다.

그림 3(a) 및 3(b)는 각각 $\mathrm{Nb}$ 함량 증가에 따른 결정립의 평균 크기 변화와 $\mathrm{Nb}(\mathrm{C}, \mathrm{N})$ 의 부피분율 변화를 이미지 분석 기(image analyzer)를 이용하여 분석한 결과이다. $\mathrm{Nb}$ 의 함량 이 증가하면 결정립의 평균 크기는 $14.28 \mu \mathrm{m}$ 에서 $10.52 \mu \mathrm{m}$ 으로 줄어들고 $\mathrm{Nb}(\mathrm{C}, \mathrm{N})$ 의 부피분율은 $0.50 \mathrm{vol} \%$ 에서 1.29 $\mathrm{vol} \%$ 으로 증가하는 것으로 확인되었다.

\section{2. 공식부식거동}

그림 4는 두 합금 표면에 부동태 피막과 대기산화 피막이 형성되었을 때 각각의 공식부식저항성을 알아보기 위하여
$\mathrm{Cl}^{-}$을 포함하는 완충용액에서 전위주사속도를 $2 \mathrm{mV} / \mathrm{s}$ 로 양 극분극시험을 수행한 실험결과이다. $\mathrm{pH} 8.5$ 의 borate-phosphatecitric 완충용액을 사용한 이유는, $\mathrm{Fe}$ 계 합금의 경우 본 용액 에서 안정하고 두꺼운 피막이 형성된다고 보고되었기 때문 이다 [18]. 각 합금 별 및 피막 속성 별(부동태 피막, 대기산화 피막)로 각각 5 회 이상 분극시험을 수행하였고 우수한 재현 성이 확인되었으며, 이 중 대표적인 분극시험 결과를 그림 4 에 나타내었다.

대기산화 피막이 형성된 상태와 대기산화 피막을 제거하 고 부동태 피막을 형성시킨 두 조건 모두에서, 두 합금은 $\mathrm{E}_{\mathrm{corr}}$ 에서부터 부동태 상태를 나타내었고 전체적인 분극거동의 양상은 유사하였다. 주목할 만한 차이는 $\mathrm{E}_{\mathrm{pit}}$ 및 부동태 전류 밀도(passive current density, $\mathrm{i}_{\text {passive }}$ )에서 관찰되었다. 대기산 화 피막이 형성되어 있는 경우, $0.1 \mathrm{Nb}, 0.2 \mathrm{Nb}$ 합금의 $\mathrm{E}_{\mathrm{pit}}$ 은 각각 $0.307 \mathrm{~V}_{\mathrm{SCE}}, 0.316 \mathrm{~V}_{\mathrm{SCE}}$ 이었고, 부동태 피막이 형성된 경우의 두 합금의 $\mathrm{E}_{\mathrm{pit}}$ 은 각각 $0.427 \mathrm{~V}_{\mathrm{SCE}}, 0.438 \mathrm{~V}_{\mathrm{SCE}}$ 이었다. $\mathrm{Nb}$ 함량이 높은 $0.2 \mathrm{Nb}$ 합금에서 상대적으로 높은 $\mathrm{E}_{\mathrm{pit}}$ 이 관찰 되었으며, 또한 대기산화 피막에 비하여 부동태 피막의 $\mathrm{E}_{\mathrm{pit}}$ 이 높았다(그림 4(c)). 또한, 대기산화 피막의 형성 여부에 따른

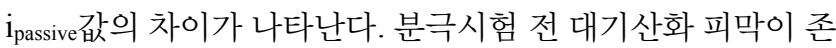
재할 경우, $\mathrm{E}_{\mathrm{corr}}$ 부터 약 $0 \mathrm{~V}_{\mathrm{SCE}}$ 까지 전위구간에서의 $\mathrm{i}_{\text {passive } \text { 값 }}$ 은 두 합금 모두에서 대기산화 피막이 존재하지 않는 샘플에 비하여 약 $1 / 2$ 의 수준으로 낮다. 그러나 분극시험 중 인가전 위가 약 $0 \mathrm{~V}_{\mathrm{SCE}}$ 이상이 되어 안정한 부동태 피막이 형성되면 두 합금 모두에서 대기산화 피막의 형성 유무에 관계없이

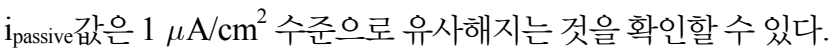

$\mathrm{E}_{\mathrm{pit}}$ 의 차이를 재확인하기 위하여 동일 용액, 동일 조건하 에서 전위주사속도만을 변화 $(2 \rightarrow 5 \mathrm{mV} / \mathrm{s})$ 시켜 분극시험을 추 가로 수행하였고, 그 결과를 그림 5에 나타내었다. 대기산화 

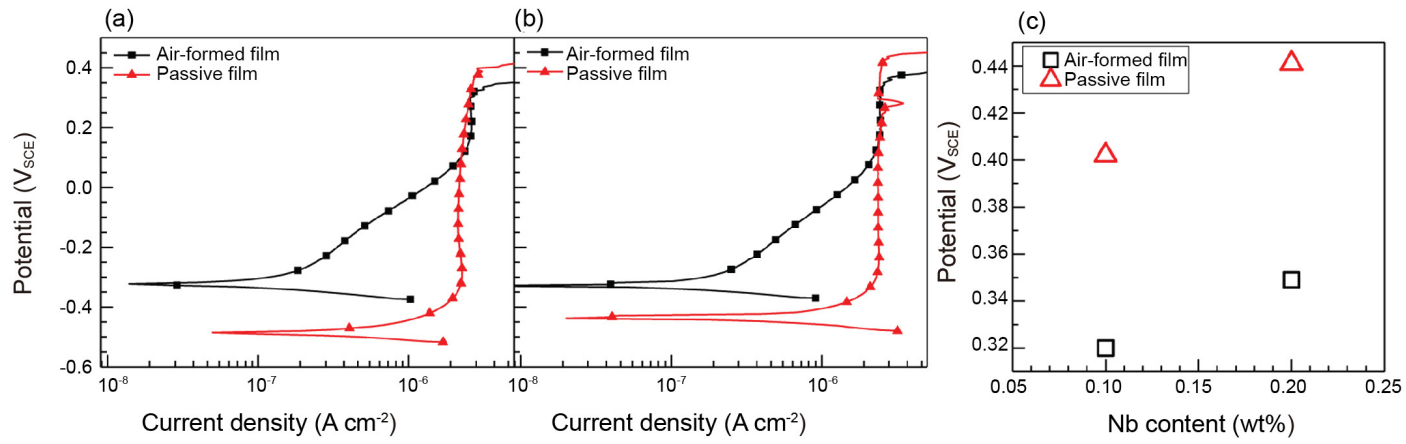

Fig. 5. Potentiodynamic polarization curves of (a) $0.1 \mathrm{Nb}$ and (b) $0.2 \mathrm{Nb}$ alloys measured in buffered $0.6 \mathrm{M} \mathrm{NaCl}$ solution (borate-phosphate-citric buffer, $\mathrm{pH} 8.5$ ) at $25{ }^{\circ} \mathrm{C}$ at a potential sweep rate of $5 \mathrm{mV} / \mathrm{s}$. (c) Pitting potential values of the specimens.

피막이 형성되어 있는 경우, $0.1 \mathrm{Nb}, 0.2 \mathrm{Nb}$ 합금의 $\mathrm{E}_{\mathrm{pit}}$ 은 각각 $0.320,0.349 \mathrm{~V}_{\mathrm{SCE}}$ 이었고, 부동태 피막이 형성된 경우의 두 합금의 $\mathrm{E}_{\mathrm{pit}}$ 은 각각 $0.402,0.441 \mathrm{~V}_{\mathrm{SCE}}$ 이었다. 그림 4 의 결과 와 마찬가지로 두 합금 모두에서 대기산화 피막에 비해 부동 태 피막의 $\mathrm{E}_{\mathrm{pit}}$ 이 높고, $\mathrm{Nb}$ 의 함량이 높은 합금의 $\mathrm{E}_{\mathrm{pit}}$ 이 높은 것을 확인할 수 있었다(그림 5(c)). 또한, 그림 4에서도 관찰 된 바와 같이 두 합금 모두에서 대기산화 피막이 형성되어 있 는 샘플이 대기산화 피막을 형성하지 않은 샘플에 비하여

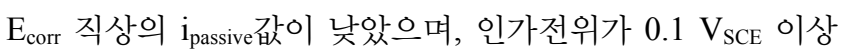
이 되면 전류밀도가 약 $2 \mu \mathrm{A} / \mathrm{cm}^{2}$ 수준으로 유사해졌다. $\mathrm{E}_{\mathrm{corr}}$ 직상의 전위영역에서 관찰되는 대기산화피막의 유무에 따른 $\mathrm{i}_{\text {passive }}$ 차이는 분극시험 전 이미 형성되어있는 대기산화 피막 에 의해 전자의 이동이 제한을 받기 때문으로 판단된다. 그림 4 와 그림 5 의 결과로부터, $\mathrm{Nb}$ 의 함량 증가에 따른 공식저항 성 상승을 확인할 수 있고, 또한 부동태 피막은 대기산화 피 막에 비해 보호성이 우수함을 알 수 있었다.

따라서, 두 합금의 $\mathrm{E}_{\mathrm{pit}}$ 을 결정하는 주요요인은 $\mathrm{Nb}$ 의 함량 과 피막 속성(대기산화 피막 또는 부동태 피막)임을 확인하 였다. 본 논문의 연구 합금에 첨가된 $\mathrm{Nb}$ 는 모재의 네 가지 특 성, 즉, (1) 모재 내 고용상의 $\mathrm{Nb}$ 농도, (2) $\mathrm{Nb}(\mathrm{C}, \mathrm{N})$ 의 부피분 율, (3) 탄질화물 형성으로 인한 모재 내 고용상의 $\mathrm{N}$ 및 $\mathrm{C}$ 농 도, 그리고 (4) 결정립크기를 변화시킨다. $\mathrm{Nb}$ 함량에 따라 변 화하는 이들 요소는 개별적 또는 복합적으로 모재의 공식저 항성 변화를 야기할 수 있다. 따라서, 각 요소의 역할을 독립 적으로 고찰하여 이하에 정리하였다.

첫째로, 모재 내 고용상의 $\mathrm{Nb}$ 농도에 대해 조사한 결과, 모 재에 포함된 $\mathrm{C}$ 및 $\mathrm{N}$ 의 함량은 첨가된 $\mathrm{Nb}$ 를 소모하기에 충분 하기 때문에 고용상의 $\mathrm{Nb}$ 농도는 매우 낮다는 것을 열역학계 산을 통해 확인하였다. 고용상의 $\mathrm{Nb}$ 함량은 $0.1 \mathrm{Nb}$ 합금의 경 우 $1.422 \times 10^{-2} \mathrm{wt} \%, 0.2 \mathrm{Nb}$ 합금에서는 $1.454 \times 10^{-2} \mathrm{wt} \%$ 이
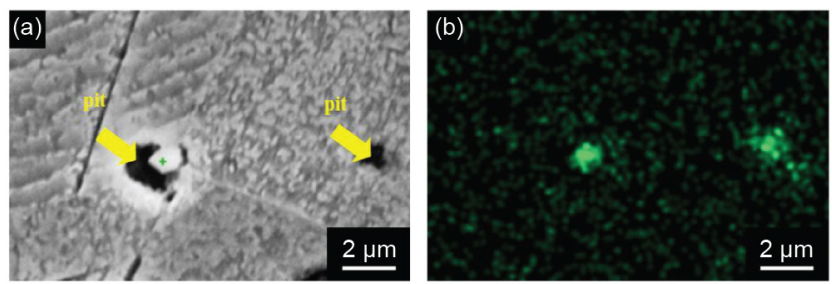

Fig. 6. (a) SEM micrograph of corroded $0.2 \mathrm{Nb}$ alloy and (b) corresponding EDS map of $\mathrm{Nb}$. Pits are indicated by arrows.

며, 따라서 두 합금간의 고용 $\mathrm{Nb}$ 농도의 차이는 $3.2 \times 10^{-4}$ $\mathrm{wt} \%$ 에 불과하다. $0.1 \mathrm{Nb}$ 및 $0.2 \mathrm{Nb}$ 합금에서, 이와 같은 고용 상의 $\mathrm{Nb}$ 농도의 차이는 두 합금의 공식저항성을 의미 있는 수준으로 변화시킬 수 없을 것으로 보인다.

둘째로, $\mathrm{Nb}(\mathrm{C}, \mathrm{N})$ 과 공식저항성의 상관관계를 조사하였다. 두 합금의 공식발생처를 조사한 결과, 모재 내 형성된 조대한 $\mathrm{Nb}(\mathrm{C}, \mathrm{N})$ 과 인접한 모재에서 공식이 발생한 것을 확인하였다 (그림 6). 따라서, $\mathrm{Nb}$ 첨가에 따른 $\mathrm{Nb}(\mathrm{C}, \mathrm{N})$ 의 분율 증가(그림 $3(\mathrm{~b})$ )는 공식발생의 확률을 증가시킬 것으로 판단해야 한다. 그러나, 분극시험 결과(그림 4, 5) $0.2 \mathrm{wt} \% \mathrm{Nb}$ 를 포함하는 합 금의 $\mathrm{Nb}(\mathrm{C}, \mathrm{N})$ 분율이 높음에도 불구하고 $0.2 \mathrm{Nb}$ 합금의 공식 저항성은 높았다. 이는 부동태 피막의 보호성 향상으로 해석 해야 한다고 판단된다.

셋째로, $\mathrm{Nb}$ 첨가에 의한 $\mathrm{Nb}(\mathrm{C}, \mathrm{N})$ 의 형성은 모재 내 고용상 의 $\mathrm{C}$ 및 $\mathrm{N}$ 의 농도를 감소시킬 수 있다. 열역학 계산을 통해 확인한 결과, $\mathrm{Nb}$ 함량이 $0.1 \mathrm{wt} \%$ 에서 $0.2 \mathrm{wt} \%$ 로 증가하면 고용상의 $\mathrm{C}$ 의 농도는 $2.84 \times 10^{-3} \mathrm{wt} \%$ 에서 $2.72 \times 10^{-3} \mathrm{wt} \%$ 로, 그리고 고용상의 $\mathrm{N}$ 의 농도는 $2.82 \times 10^{-3} \mathrm{wt} \%$ 에서 $2.69 \times$ $10^{-3} \mathrm{wt} \%$ 로 감소한다. 두 합금의 고용상의 $\mathrm{C}$ 및 $\mathrm{N}$ 함량변화 는 각각 $1.2 \times 10^{-4} \mathrm{wt} \%$ 및 $1.3 \times 10^{-4} \mathrm{wt} \%$ 로, 공식저항성을 변화시키기엔 매우 낮은 변화량을 나타내므로 공식저항성 


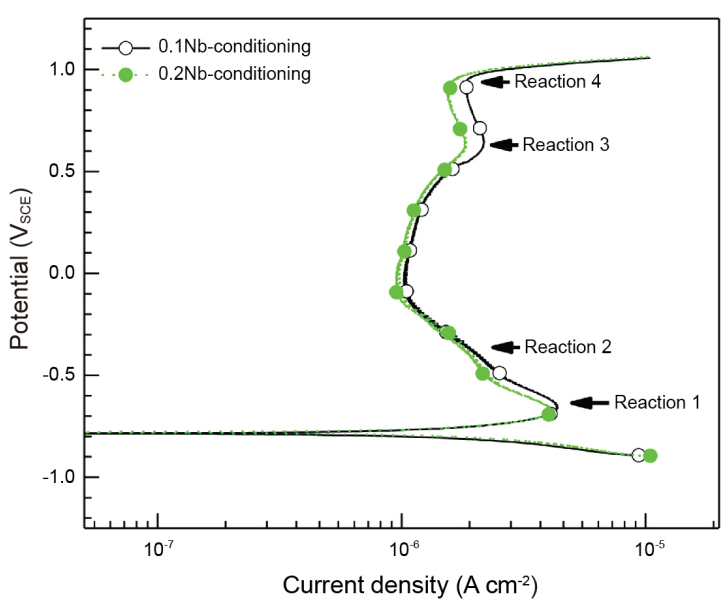

Fig. 7. Potentiodynamic polarization curves of $0.1 \mathrm{Nb}$ and $0.2 \mathrm{Nb}$ alloys measured in buffer solution (borate-phosphate-citric buffer, $\mathrm{pH} 8.5$ ) at $25{ }^{\circ} \mathrm{C}$ at a potential sweep rate of $2 \mathrm{mV} / \mathrm{s}$.

변화 원인에서 배제할 수 있다 $[12,14,15,19]$.

마지막으로, $\mathrm{Nb}$ 첨가로 인한 결정립 미세화를 고려하여야 한다. $\mathrm{Nb}$ 함량 증가에 따라 결정립 크기는 약 $26.3 \%$ 의 감소 $(14.28 \rightarrow 10.52 \mu \mathrm{m}$, 그림 3(a)) 를 나타낸다. $\mathrm{Nb}$ 의 첨가에 따 라 변화할 수 있는 모재의 속성을 고려한 결과, $\mathrm{Nb}$ 함량 증가 에 따라 고용상의 $\mathrm{Nb}, \mathrm{C}$, 그리고 $\mathrm{N}$ 의 함량 변화는 무시할 수 있는 수준이며 $\mathrm{Nb}(\mathrm{C}, \mathrm{N})$ 의 부피분율 증가는 오히려 공식저항 성을 저해할 것으로 판단되므로, $\mathrm{Nb}$ 첨가에 따른 공식저항성 상승, 즉 피막 보호성 향상은 결정립 미세화와 연계하여 해석
하는 것이 합리적으로 보인다.

또한, 그림 4 및 5 에 나타난 바와 같이, 두 합금의 공식전위 는 피막의 속성에 따라서도 변화하였다. 두 합금 모두에서 대 기산화 피막이 형성된 경우 부동태 피막이 형성된 경우에 비 해 낮은 $\mathrm{E}_{\mathrm{pit}}$ 을 나타내었다. 상술한 바와 같이, $\mathrm{Nb}$ 함량 증가 에 따른 결정립 미세화가 피막 보호성에 영향을 주었을 것이 며, 또한 피막 속성에 따라서도 피막의 보호성은 변화하였을 것으로 예측되므로, 이후, 공식전위의 변화를 해석하기 위해 두 합금 각각의 피막 속성에 따른 물리화학적 및 전자적 특성 을 분석하였다.

\section{3. 부동태 거동}

산화 피막 분석을 위하여, 두 합금의 부동태 거동 및 부동 태 전위영역을 조사하였다. $\mathrm{Cl}^{-}$을 포함하지 않은 완충용액 $(\mathrm{pH} 8.5)$ 에서 양극분극시험(전위 주사 속도 $=2 \mathrm{mV} / \mathrm{s})$ 을 수 행하였고 그 결과를 그림 7에 나타내었다. 두 합금의 분극거 동은 매우 유사하며, 부식전위는 약 $-0.79 \mathrm{~V}_{\mathrm{SCE}}$ 로 측정되었 다. 두 합금 모두에서 특정 전위에서 전류 증가가 관찰되는 데, 먼저 $-0.67 \mathrm{~V}_{\mathrm{SCE}}$ (Reaction 1)에서의 전류증가는 $\mathrm{Fe} \rightarrow$ $\mathrm{Fe}^{2+}$ 및 $\mathrm{Cr} \rightarrow \mathrm{Cr}^{3+}$ 의 산화 반응에 해당하며, $-0.41 \mathrm{~V}_{\mathrm{SCE}}$ (Reaction 2)에서의 전류증가는 $\mathrm{Fe}^{2+} \rightarrow \mathrm{Fe}^{3+}$ 의 반응, 그리고 $0.67 \mathrm{~V}_{\mathrm{SCE}}$ (Reaction 3)에서의 전류증가는 $\mathrm{Cr}^{3+} \rightarrow \mathrm{Cr}^{6+}$ 의 산 화반응에 기인한다. 마지막으로 $0.95 \mathrm{~V}_{\mathrm{SCE}}$ (Reaction 4)이상
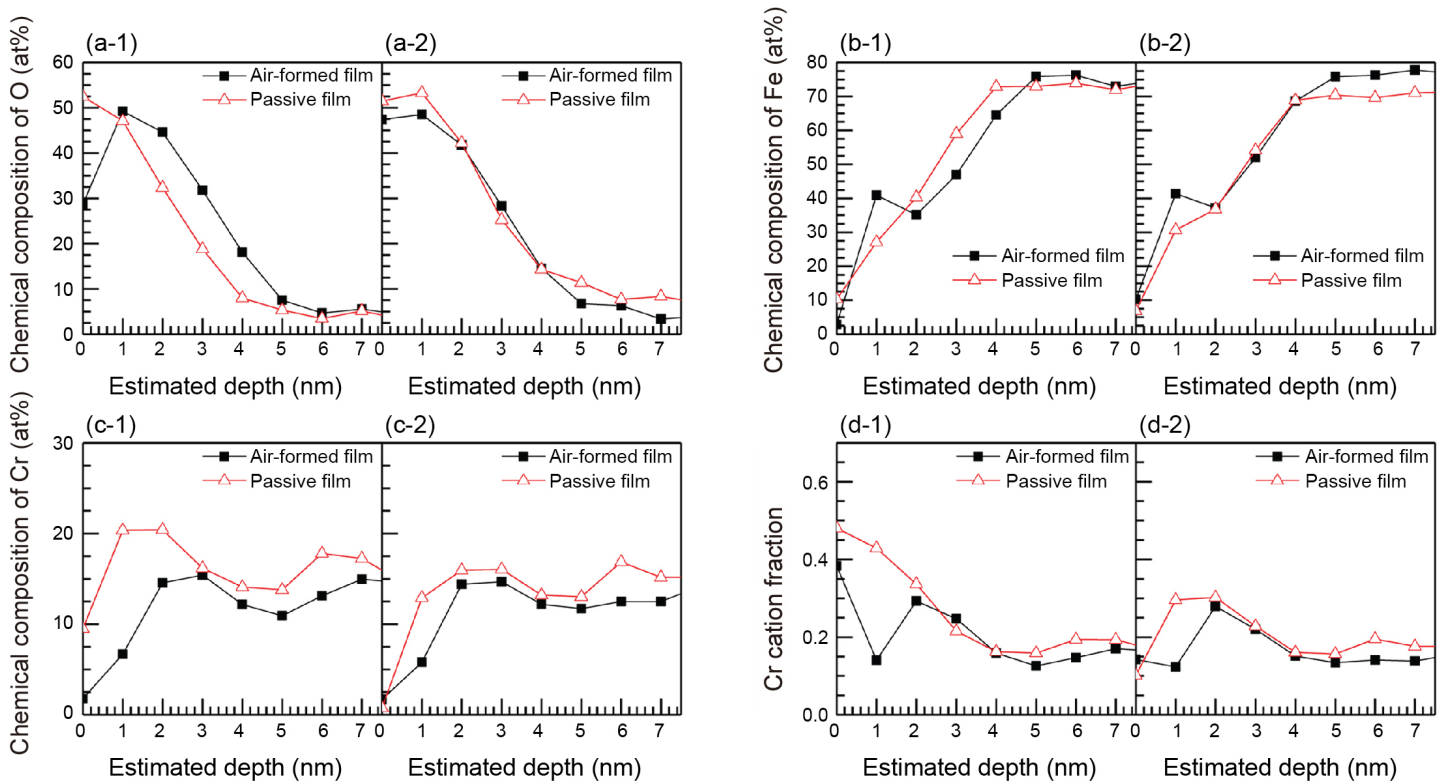

Fig. 8. Chemical composition depth profiles of the passivated surface of the $0.1 \mathrm{Nb}$ and $0.2 \mathrm{Nb}$ alloys: (a-1 and a-2) $\mathrm{O}$, (b-1 and b-2) Fe, (c-1 and c-2) $\mathrm{Cr}$, and (d-1 and d-2) cation fraction of $\mathrm{Cr}([\mathrm{Cr} / \mathrm{Cr}+\mathrm{Fe}])$ of $0.1 \mathrm{Nb}$ and $0.2 \mathrm{Nb}$ alloys, respectively. 


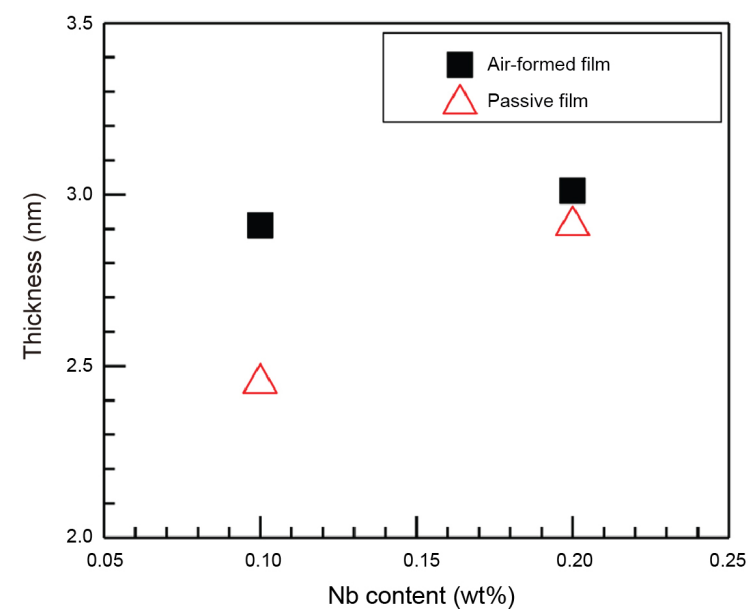

Fig. 9. Estimated thickness values of the air-formed and passive films of $0.1 \mathrm{Nb}$ and $0.2 \mathrm{Nb}$ alloys.

에서의 전류증가는 transpassive 반응에 의한 것으로, 본 $0.1 \mathrm{Nb}$ 및 $0.2 \mathrm{Nb}$ 합금의 분극거동은 완충용액에서 나타나는 스테인리스강의 전형적인 분극거동 [20,21]과 유사한 양상을 나타낸다. 그림 6 의 분극곡선으로부터, 두 합금의 부동태 전 위영역은 $\mathrm{E}_{\mathrm{corr}}$ 부터 transpassive 전위로 한정할 수 있고, 따라 서 본 분극곡선에 기초하여 이후 부동태 피막연구를 위한 부 동태 피막 형성전위를 결정하였다. 특징적으로, $0.1 \mathrm{Nb}$ 가 $0.2 \mathrm{Nb}$ 에 비해 전체 전위 영역에서 근소하게 높은 전류밀도 값을 나타내는 차이점이 관찰되었는데, 이로부터 $0.2 \mathrm{Nb}$ 가 $0.1 \mathrm{Nb}$ 에 비해 더 안정한 피막을 가지고 있다는 것으로 판단 할 수 있다.

\section{4. 산화 피막 분석: XPS}

먼저, 두 합금의 대기산화 피막과 부동태 피막의 물리적 화 학적 특성을 XPS를 이용하여 조사하였다. $0.1 \mathrm{Nb}$ 및 $0.2 \mathrm{Nb}$ 합금의 대기산화 피막과 부동태 피막의 표면으로부터 깊이 에 따른 $\mathrm{O}$ (그림 8(a-1), 8(a-2)), $\mathrm{Fe}($ 그림 8(b-1), 8(b-2)), $\mathrm{Cr}$ (그 림 $8(\mathrm{c}-1), 8(\mathrm{c}-2))$ 의 농도 $(\mathrm{at} \%)$ 변화와, $\mathrm{Cr}$ 양이온분율 $[\mathrm{Cr} /(\mathrm{Cr}$ $+\mathrm{Fe})]$ (그림 8(d-1), 8(d-2))을 그림 8에 나타내었다.

두 합금 모두의 대기산화 피막과 부동태 피막은 $(\mathrm{Fe}, \mathrm{Cr})$-산 화물(oxide)로 서로 비슷한 화학구조를 가진 것으로 확인되었 고 피막 내 $\mathrm{Nb}$ 는 거의 검출되지 않았다. 이 결과는, 모재 내 고 용상태의 $\mathrm{Nb}$ 의 함량이 매우 낮은 것과, 안정한 $\mathrm{Nb}(\mathrm{C}, \mathrm{N})$ 은 부 동태 피막 형성에 관여하지 않음을 간접적으로 나타낸다. 또 한 그림 8(c-1), 8(c-2)는 부동태 피막이 대기산화 피막보다 높 은 $\mathrm{Cr}$ 농도를 가지는 것을 보여준다. $\mathrm{Cr}$ 은 $\mathrm{Fe}$ 보다 반응성이 뛰어난 금속이나, 수용액 중에서 $\mathrm{Cr}$ 은 $\mathrm{Fe}$ 에 비해 산화물 형성
능이 우수하고 산화 피막 내에서 $\mathrm{Cr}$ 에 비해 $\mathrm{Fe}$ 가 우선적으로 용해되므로[22], 부동태 피막이 대기산화 피막에 비해 피막 내 $\mathrm{Cr}$ 농도가 높은 것을 이해할 수 있다. 그림 8(a-1), 8(a-2)의 산소 농도로부터 측정한 두 합금의 대기산화 피막 및 부동태 피막의 두께를 그림 9에 나타냈다. $0.1 \mathrm{Nb}$ 의 대기산화 피막과 부동태 피막의 두께는 각각 $2.91 \mathrm{~nm}$ 와 $2.45 \mathrm{~nm}$ 이었고 $0.2 \mathrm{Nb}$ 의 대기산화 피막과 부동태 피막의 두께는 각각 $3.01 \mathrm{~nm}$ 와 $2.91 \mathrm{~nm}$ 이었다. $\mathrm{Nb}$ 의 함량이 증가할수록 부동태 피막의 두 께는 증가하였고 대기산화 피막이 부동태 피막에 비해 대체 로 두꺼웠다.

일반적으로 스테인리스강의 경우 표면 산화 피막 내 $\mathrm{Cr}$ 농 도가 증가할수록 피막의 보호성이 증가한다고 알려져 있다 $[3,22,23]$, 대기산화 피막이 부동태 피막에 비해 두꺼우나(그 림 9) 피막 내 $\mathrm{Cr}$ 농도는 낮은 것으로 확인되었기에(그림 $8(\mathrm{c}-1), 8(\mathrm{c}-2))$, 두 합금 모두에서 부동태 피막이 형성된 경우 대기산화 피막에 비해 피막 내 $\mathrm{Cr}$ 의 함량이 높았으므로 이에 의해 $\mathrm{E}_{\mathrm{pit}}$ 의 상승이 야기되었음을 일차적으로 해석할 수 있으 며, 공식저항성을 결정함에 있어서는 피막 두께보다 피막 내 $\mathrm{Cr}$ 함량이 더욱 중요한 것으로 예측할 수 있었다. 그러나 이 러한 해석은 $0.1 \mathrm{Nb}$ 합금과 $0.2 \mathrm{Nb}$ 합금의 경우에는 적용되지 않음이 확인되었다. $0.1 \mathrm{Nb}$ 합금과 $0.2 \mathrm{Nb}$ 합금을 비교하면, $0.2 \mathrm{Nb}$ 합금은 $0.1 \mathrm{Nb}$ 합금에 비해 피막 두께는 소폭 증가하나 (그림 9) 피막 내 $\mathrm{Cr}$ 농도는 낮다(그림 8(c-1), 8(c-2)). 피막 내 낮은 $\mathrm{Cr}$ 농도를 지님에도 불구하고 $0.2 \mathrm{Nb}$ 의 $\mathrm{E}_{\mathrm{pit}}$ 은 $0.1 \mathrm{Nb}$ 합 금에 비해 높은데, 이 결과는 피막 내 $\mathrm{Cr}$ 함량 변화 요인만으 로는 모재 내 $\mathrm{Nb}$ 함량의 변화에 따른 공식저항성 변화를 해 석하기 어렵다. 즉, $\mathrm{Nb}$ 함량 증가 및 피막 두께의 속성 변화에 따른 $\mathrm{E}_{\mathrm{pit}}$ 의 변화 경향은 피막의 두께, 피막 내 $\mathrm{Cr}$ 농도의 물리 -화학적 특성만으로는 일관성있게 해석할 수 없다. 따라서 이 후 산화 피막의 전자적 특성 분석을 추가적으로 수행하였고, 이 결과에 기초하여 $\mathrm{E}_{\mathrm{pit}}$ 의 변화 원인을 해석하고자 하였다.

\section{5. 산화 피막 분석: Mott-Schottky analysis}

부동태 현상을 나타내는 금속의 피막은 oxygen vacancies $\left(\mathrm{V}_{\mathrm{O}}{ }^{2+}\right)$, metal vacancies $\left(\mathrm{V}_{\mathrm{M}}{ }^{\mathrm{X}-}\right)$, cation interstitials $\left(\mathrm{M}_{\mathrm{i}}^{\mathrm{X}+}\right)$ 와 같은 많은 수의 점결함을 포함하기 때문에 반도체적 성질을 나타낸다. 피막의 전자적 특성을 분석하는 여러 in-situ 방법 중 Mott-Schottky 분석을 이용하면 평탄대 전위(flat band potential), 점결함농도 등 부동태 피막의 전자적 특성에 관한 중요 정보를 얻을 수 있다. 부동태 피막의 공간전하층(space charge layer)의 전기용량(capacitance, $\mathrm{C}_{\mathrm{SC}}$ )를 인가전위에 따 

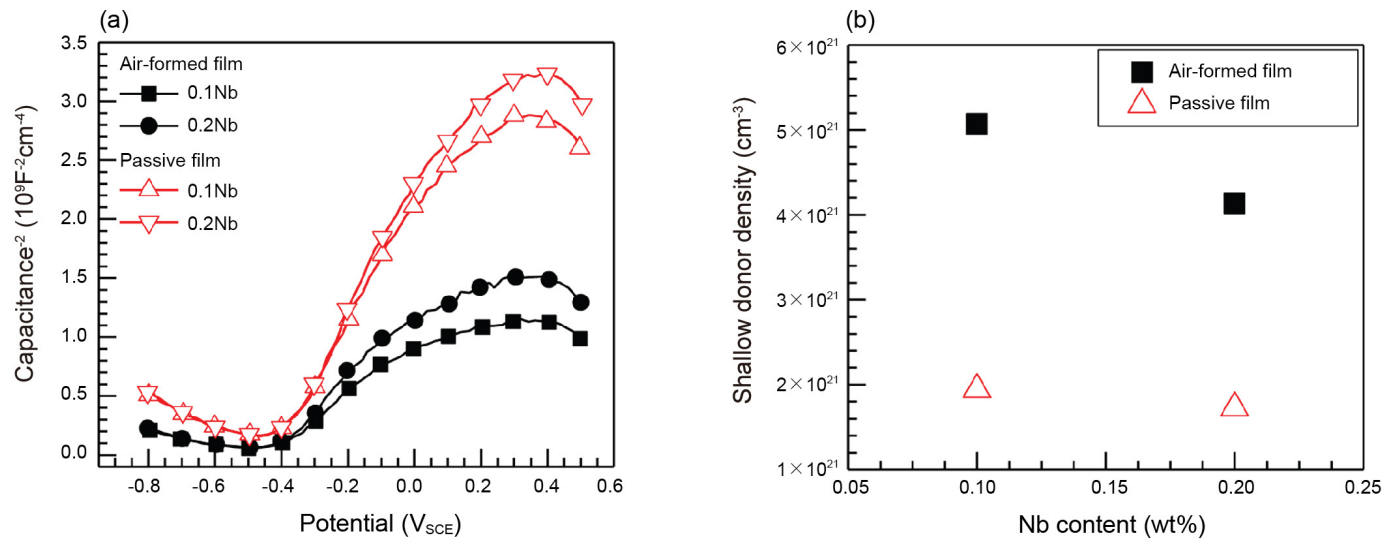

Fig. 10. (a) Mott-Schottky plots of the $0.1 \mathrm{Nb}$ and $0.2 \mathrm{Nb}$ alloys measured in the buffer solution (borate-phosphate-citric buffer, $\mathrm{pH} 8.5$ ) with decreasing applied potential from $0.5 \mathrm{~V}_{\mathrm{SCE}}$ to $-0.8 \mathrm{~V}_{\mathrm{SCE}}$ by imposing sinusoidal voltage perturbation of $\pm 10 \mathrm{mV}$ at a frequency of 1 $\mathrm{kHz}$. (b) Shallow donor density values of the air-formed and passive films of $0.1 \mathrm{Nb}$ and $0.2 \mathrm{Nb}$ alloys.

라 측정하면, 다음의 Mott-Schottky 관계식으로부터 반도체 의 종류(n-type, p-type)와 점결함농도, 평탄대 전위 등을 구 할 수 있다.

$$
\frac{1}{C_{S C}^{2}}=\frac{1}{C_{\text {total }}^{2}}-\frac{1}{C_{H}^{2}}=\left(\frac{2}{\varepsilon \varepsilon_{0} e N_{d}}\right)\left(E_{a p p}-E_{f b}-\frac{\kappa_{B} t}{e}\right)
$$

(for an n-type)

(equation 1)

$$
\frac{1}{C_{S C}^{2}}=\frac{1}{C_{\text {total }}^{2}}-\frac{1}{C_{H}^{2}}=-\left(\frac{2}{\varepsilon \varepsilon_{0} e N_{d}}\right)\left(E_{a p p}-E_{f b}+\frac{\kappa_{B} t}{e}\right)
$$

(for a p-type)

(equation 2)

여기서, $\varepsilon$ 는 유전상수(dielectric constant)이고, 일반적으로 스테인리스강의 유전상수는 15.6 이다 $[3,24] . \varepsilon_{0}$ 는 진공유전 율(vacuum permittivity, $8.854 \times 10^{-14} \mathrm{~F} \mathrm{~cm}^{-2}$ ), e는 전자 한 개 의 전하량 $\left(1.6 \times 10^{-19} \mathrm{C}\right), \mathrm{k}_{\mathrm{B}}$ 는 볼쯔만 상수 $\left(1.385 \times 10^{-23}\right.$ $\mathrm{J} / \mathrm{deg}), \mathrm{T}$ 는 절대 온도 $(\mathrm{K}), \mathrm{E}_{\mathrm{fb}}$ 는 평탄대 전위(flat band potential), $\mathrm{N}_{\mathrm{d}}$ 는 도너 밀도(donor density), $\mathrm{N}_{\mathrm{a}}$ 는 억셉터 밀도 (accepter density)를 나타낸다. 이 때 측정되는 부동태 피막 내 $\mathrm{N}_{\mathrm{d}}$ 와 $\mathrm{N}_{\mathrm{a}}$ 는 피막의 특성 및 파괴 거동을 이해하는 매우 중 요한 정보가 된다.

그림 10(a)는 borate-phosphate-citric 완충용액 $(\mathrm{pH} 8.5)$ 에 서 측정한 Mott-Schottky 분석결과이다. 그림 10(a)에서 두 합금의 부동태 피막과 대기산화 피막 모두 $-0.4 \mathrm{~V}_{\mathrm{SCE}}$ 이상에 서 양(+)의 기울기를 나타내는데 이는 두 합금 표면에 형성된 안정한 산화피막이 n-type 반도체임을 의미한다[16,17,20]. $0.1 \mathrm{Nb}$ 및 $0.2 \mathrm{Nb}$ 합금의 피막은 그림 8 의 XPS 분석결과에서
나타난 바와 같이 $(\mathrm{Fe}, \mathrm{Cr})$-산화물이며, 이는 기존 문헌에 보 고된 일반적인 스테인리스강의 산화 피막의 기본 구조와 잘 일치한다. 이와 같은 스테인리스강 표면에 형성된 n-type 피 막의 경우, 피막 내에 존재하는 도너(donor) 중 지배적이고 측정 가능한 도너는 $\mathrm{V}_{\mathrm{O}}{ }^{2+}$ 이다 [21]. Mott-Schottky 분석을 통 해 $\mathrm{V}_{\mathrm{O}}{ }^{2+}$ 의 농도 $\left(\mathrm{N}_{\mathrm{d}}\right)$ 를 구하여 $\mathrm{Nb}$ 의 함량 및 피막 속성에 따라 그림 $10(\mathrm{~b})$ 에 도시하였다. $0.1 \mathrm{Nb}$ 의 대기산화 피막과 부동태 피막의 $\mathrm{N}_{\mathrm{d}}$ 는 각각 $5.07 \times 10^{21} \mathrm{~cm}^{-3}$ 와 $1.95 \times 10^{21} \mathrm{~cm}^{-3}$ 로 대기 산화 피막의 $\mathrm{N}_{\mathrm{d}}$ 값이 2.5 배 이상 높았으며, $0.2 \mathrm{Nb}$ 의 대기산화 피막과 부동태 피막의 $\mathrm{N}_{\mathrm{d}}$ 는 각각 $4.13 \times 10^{21} \mathrm{~cm}^{-3}$ 와 $1.72 \times$ $10^{21} \mathrm{~cm}^{-3}$ 로, $0.2 \mathrm{Nb}$ 역시 대기산화 피막의 $\mathrm{N}_{\mathrm{d}}$ 값이 2.4 배 높 았다. $0.1 \mathrm{Nb}$ 와 $0.2 \mathrm{Nb}$ 의 $\mathrm{N}_{\mathrm{d}}$ 를 비교하면, $0.2 \mathrm{Nb}$ 의 부동태 및 대 기산화 피막 모두 $0.1 \mathrm{Nb}$ 에 비해 낮은 $\mathrm{N}_{\mathrm{d}}$ 값을 갖는 것이 확인 되었다.

두 합금 모두에서 부동태 피막이 형성된 경우 대기산화 피 막에 비해 $\mathrm{N}_{\mathrm{d}}$ 가 낮았다. 또한, $\mathrm{Nb}$ 의 함량이 증가할수록 피막 의 $\mathrm{N}_{\mathrm{d}}$ 는 낮아졌다. 따라서, $0.1 \mathrm{Nb}$ 와 $0.2 \mathrm{Nb}$ 를 비교할 때, 그 리고 두 합금에서 부동태 피막과 대기산화 피막을 비교할 때 모두, $\mathrm{N}_{\mathrm{d}}$ 가 낮은 경우 $\mathrm{E}_{\mathrm{pit}}$ 이 높아지는 경향이 잘 일치한다. 피 막의 물리-화학적 특성, 즉 피막의 두께와 피막 내 $\mathrm{Cr}$ 의 농도 변화의 결과만으로는 피막 속성과 $\mathrm{Nb}$ 함량에 따른 $\mathrm{E}_{\mathrm{pit}}$ 의 변 화를 해석하는 데에 논리적 모순이 있었으나, 피막의 전자적 특성 분석결과인 피막 내 $\mathrm{N}_{\mathrm{d}}$ 를 고려하면 피막속성과 $\mathrm{Nb}$ 함 량에 따른 $\mathrm{E}_{\mathrm{pit}}$ 변화 양상을 일관되게 해석할 수 있었다.

정리하면, 본 연구에서 사용된 합금조성의 탄질소강에서 $\mathrm{Nb}$ 함량이 증가하면 산화 피막 두께는 상승하고 피막 내 $\mathrm{Cr}$ 농도는 낮으나, 피막 내 $\mathrm{N}_{\mathrm{d}}$ 가 낮아져서 보다 보호성 있는 피 
막을 형성하므로 강의 공식저항성을 상승시켰다. 또한 피막 속성별로 비교할 경우, 부동태 피막은 대기산화 피막에 비해 두께는 얇으며 피막 내 $\mathrm{Cr}$ 농도가 높은 특성을 나타내고 $\mathrm{N}_{\mathrm{d}}$ 가 낮아 보다 견고한 피막을 형성하므로 공식저항성이 높은 결과를 나타내었다. 산화 피막의 피막 두께, 피막 내 $\mathrm{Cr}$ 농도, 그리고 $\mathrm{N}_{\mathrm{d}}$ 등의 여러 특징 중 피막 보호성을 결정하는 가장 중요한 요인은 $\mathrm{N}_{\mathrm{d}}$ 로 판단된다. 모재 내 $\mathrm{Nb}$ 함량 증가로 인하 여 결함농도가 낮고 보호성있는 피막이 형성되는 것은 첨가 된 $\mathrm{Nb}$ 에 의한 결정립 미세화에 기인한 것으로 보인다. 즉, 결 정립 미세화로 인해 에너지적으로 불안정한 결정립계의 면 적이 증가하고 $[25,26]$ 이에 따라 전기화학적 산화 반응성이 증가하여 보다 안정하고 보호성 있는 피막을 형성한 것으로 판단된다.

\section{4. 결 론}

본 논문에서는 탄질소 스테인리스강인 $\mathrm{Fe}_{\text {balance }} 18 \mathrm{Cr} 10$ $\mathrm{Mn} 0.3 \mathrm{~N} 0.3 \mathrm{C}$ 기지 합금에 $0.1,0.2 \mathrm{wt} \%$ 의 $\mathrm{Nb}$ 를 첨가하였을 때 미세조직 변화와 공식부식저항성 변화를 평가하였고, 부 동태 피막과 대기산화 피막의 화학적, 물리적, 전자적 특성을 조사하여 다음의 결과를 얻었다.

(1) 두 합금은 $\mathrm{Nb}(\mathrm{C}, \mathrm{N})$ 이 분산되어 있는 오스테나이트 상 을 가진다. $\mathrm{Nb}$ 의 함량이 증가할수록 결정립 크기는 줄어들고 $\mathrm{Nb}(\mathrm{C}, \mathrm{N})$ 의 부피분율은 증가하였다.

(2) 두 합금의 $\mathrm{E}_{\mathrm{pit}}$ 은 $\mathrm{Nb}$ 의 함량과 피막속성에 따라 변화하 였다. $\mathrm{Nb}$ 의 함량이 증가할수록 $\mathrm{E}_{\mathrm{pit}}$ 은 증가하였으며, 부동태 피막이 대기산화 피막에 비해 높은 $\mathrm{E}_{\mathrm{pit}}$ 을 나타내었다. 공식발 생처를 조사한 결과, 조대한 $\mathrm{Nb}(\mathrm{C}, \mathrm{N})$ 과 인접한 모재에서 공 식이 발생함이 관찰되었다.

(3) XPS 분석 결과, 두 합금의 대기산화 피막과 부동태 피 막은 $(\mathrm{Fe}, \mathrm{Cr})$-산화물로 확인되었다. 높은 $\mathrm{E}_{\mathrm{pit}}$ 을 나타내는 부 동태 피막은 대기산화 피막에 비해 피막 내 $\mathrm{Cr}$ 농도는 높고 피막의 두께는 얇았으며, 높은 $\mathrm{E}_{\mathrm{pit}}$ 을 나타내는 $0.2 \mathrm{Nb}$ 는 $0.1 \mathrm{Nb}$ 에 비해 피막 두께는 증가하였으나 피막 내 $\mathrm{Cr}$ 농도는 낮았다. 그러므로, 피막 내 $\mathrm{Cr}$ 농도와 피막의 두께 변화로는 $\mathrm{Nb}$ 함량 및 피막 속성에 따른 $\mathrm{E}_{\mathrm{pit}}$ 의 변화 이유를 일관성있게 해석하기 어려운 것으로 나타났다.

(4) Mott-Schottky 분석으로 피막 내 $\mathrm{N}_{\mathrm{d}}$ 를 측정한 결과, $\mathrm{Nb}$ 함량 증가에 따라 피막 내 $\mathrm{N}_{\mathrm{d}}$ 가 감소하였고, 또한 부동태 피막 이 대기산화 피막에 비해 낮은 $\mathrm{N}_{\mathrm{d}}$ 를 나타내었다. 피막 내 $\mathrm{N}_{\mathrm{d}}$ 의 감소는 $\mathrm{Nb}$ 함량 및 피막 속성에 따른 $\mathrm{E}_{\mathrm{pit}}$ 변화를 일관되게 해
석할 수 있었다. 즉, $\mathrm{Nb}$ 함량이 증가할수록, 또한 대기산화 피 막에 비하여 부동태 피막이 형성될 경우 보다 결함이 적은 피 막이 형성되어 공식저항성이 상승한다고 해석할 수 있었다.

\section{ACKNOWLEDGEMENTS}

This study was financially supported by Fundamental Research Program (Project Number: PNK5120 and PNK5220) of the Korean Institute of Materials Science (KIMS). This study was also supported by the Ministry of Trade, Industry \& Energy (MI, Korea) under Strategic Core Materials Technology Development Program (No. 10067375).

\section{REFERENCES}

1. U. I. Thomann and P. J. Uggowitzer, Wear 239, 48 (2000).

2. V. G. Gavriljuk, B. D. Shanina, and H. Berns, Mater. Sci. Eng. A 481, 707 (2008).

3. H. Y. Ha, T. H. Lee, C. S. Oh, and S. J. Kim, Scripta Mater. 43, 121 (2009).

4. H. Y. Ha, T. H. Lee, C. S. Oh, and S. J. Kim, Steel Res. Int. 80, 488 (2009).

5. M. Schymura, F. Stegemann, and A. Fischer, Int. J. Fatigue 79, 25 (2015).

6. P. Niederhofer, L. Richrath, S. Huth, and W. Theisen, Wear 360, 67 (2016).

7. T. H. Lee, E. Shin, C. S. Oh, H. Y. Ha, and S. J. Kim, Acta Mater. 58, 3173 (2010).

8. T. H. Lee, H. Y. Ha, B. Hwang, S. J. Kim, and E. Shin, Metall. Mater. Trans. A 43, 4455 (2012).

9. M. O. Speidel, Mat.-wiss. u. Werkstofftech. 10, 875 (2006).

10. J. Rawers and N. Duttlinger, J. Mater. Sci. 24, 97 (2008).

11. V. G. Gavrilyuk and H. Berns, Met. Sci. Heat Treat. 49, 566 (2007).

12. H. Y. Ha, T. H. Lee, C. S. Oh, and S. J. Kim, Scripta Mater. 61, 121 (2009).

13. T. H. Lee, H. Y. Ha, and S. J. Kim, Metall. Mater. Trans. 42A, 3543 (2011).

14. H. Y. Ha, T. H. Lee, J. H. Jang, J. Y. Park, and J. O. Moon, Austenitic stainless steel with improved pitting corrosion resistance, KR patent 10-2016-0176117 (2016).

15. C. G. Lee, H. Y. Ha, T. H. Lee, and K. Y. Cho, J. Electrochem. Soc. 164, C591 (2017)

16. D. D. Macdonald, J. Electrochem. Soc. 139, 3434 (1992).

17. H. Y. Ha, M. H. Jang, and T. H. Lee, Electrochim. Acta. 191, 864 (2016).

18. H. Y. Ha and H. S. Kwon, J. Electrochem. Soc. 159, C416 (2012).

19. G. Bai, S. Lu, D. Li, and Y. Li, Corros. Sci. 108, 111 (2016). 
20. H. Y. Ha, T. H. Lee, and S. J Kim, Electrochim. Acta 80, 432 (2012).

21. H. Y. Ha, H. J. Jang, H. S. Kwon, and S. J. Kim, Corros. Sci. 51, 48 (2009).

22. A. A. Hermas, M. Nakayama, and K. Ogura, Electrochim. Acta 50, 2001 (2005).

23. M. Vayer, I. Reynaud, and R. Erre, J. Mater. Sci. 35,
2581 (2000).

24. S. Ningshen, U. K. Mudali, V. K. Mittal, and H. S. Khatak, Corros. Sci. 49, 481 (2007).

25. L. Liu, Y. Li, and F. Wang, Electrochim. Acta 53, 2453 (2008).

26. A. Di Schino and J. M. Kenny, Metrials Letters 57, 1830 (2003). 